\title{
CONTINUED PROGRESSIONS TOWARD IRRELEVANCE? INDIANA STATE CONSTITUTIONAL LAW SUMMARIES-2018-2019
}

\author{
SCOTT CHINN* \\ DANIEL E. PULLIAM** \\ ELIZABETH M. LITTLE ${ }^{* * *}$
}

During the survey period, ${ }^{1}$ Indiana constitutional law developments continued a trend toward a restrictive view of the constitutional rights of Hoosiers. Challenges to the criminalization of marijuana possession based on Article 1, Section 1; a prohibition against harassing telephone calls based on the right to speak; the charging of State sales tax for recreational vehicles sold to out-of-state customers; and the Right to Farm Act under the Equal Privileges and Immunities clause all failed during the survey period.

The Indiana Supreme Court also extended the admissibility of evidence derived from an illegal search to apply under the attenuation doctrine-a previously unrecognized exception to Indiana's prohibition against unreasonable searches - and held that law enforcement does not have to advise a person of their Pirtle rights before obtaining consent to a field sobriety test or blood draws. The court of appeals further limited Pirtle advisements when law enforcement obtain search warrants and denied the suppression of evidence obtained through a defendant's cell phone location data.

Referencing, without distinguishing, the federal and state constitutional provisions, the court of appeals reversed a conviction based on speedy trial rights and found a violation of due process rights in a parent termination case. The court of appeals also recognized the coequal power of the judicial branch as an aspect of the constitutional requirement that the courts remain open. Defendants charged with misdemeanors must be advised of their right to a jury trial and courts may not amend prison sentences issued under fixed plea agreements. The court of appeals also recognized that a court may not simply take judicial notice of a prior psychiatrist's finding of dangerousness to support continued seizure of a

* Scott Chinn is a partner at Faegre Drinker Biddle \& Reath LLP practicing public sector law and litigation. B.A., 1991, Indiana University; J.D., 1994, magna cum laude, Indiana University Robert H. McKinney School of Law. He is an adjunct professor at the McKinney School where he teaches Indiana Constitutional Law. Former Editor-in-Chief of the Indiana International and Comparative Law Review. He clerked for Judge David F. Hamilton, then District Judge, U.S. District Court, Southern District of Indiana.

** Daniel Pulliam is a partner in the business litigation group at Faegre Drinker Biddle \& Reath LLP. B.A., 2004, cum laude, Butler University, Indianapolis; J.D., 2010, magna cum laude, Indiana University Robert H. McKinney School of Law. He is also a former Editor-in-Chief of the Indiana Law Review and The Butler Collegian and a former law clerk for Judge John Daniel Tinder on the United States Court of Appeals for the Seventh Circuit.

*** Elizabeth Little is an associate in the finance and restructuring group at Faegre Drinker Biddle \& Reath LLP. B.A., 2011, Indiana University-Purdue University of Indianapolis; J.D., 2016, summa cum laude, Indiana University Robert H. McKinney School of Law. She is a former Executive Notes Editor of the Indiana Law Review.

1. The authors thank Catie Wheatley for her invaluable assistance in gathering the materials for this article. The authors also thank Kristina Shover, May 2020 graduate of Robert H. McKinney School of Law, for her invaluable assistance in compiling the citations for this article. 
Hoosier's firearms - the State must present fresh evidence to support the deprivation of that constitutional right.

The areas substantively addressed by Indiana's appellate courts increased to fifteen. ${ }^{2}$ Substantive decisions in the areas of government searches and double jeopardy continue to issue regularly, with the courts continuing to identify double jeopardy violations sue sponte.

Finally, Chief Justice Loretta H. Rush, with Marie Forney Miller, addressed the status of state constitutional law across the country in an article that noted litigants' failure "to bring or adequately argue state constitutional claims that offer potential relief." 3 Because of this, "powerful liberty protections sit latent from disregard," creating "a high risk that individuals" rights are trampled without redress - simply because the rightsholder or their attorneys didn't argue a state constitutional claim." ${ }^{4}$ The article proposes some approaches for fulfilling this crucial obligation, including judicial law review articles, ${ }^{5}$ and encourages judges to encourage the raising and assertion of such arguments by deciding separately state constitutional law arguments in opinions. ${ }^{6}$ State supreme courts should also develop "a principled decision-making process faithful to the constitution's history and function." Whether such developments progress in Indiana constitutional law will be monitored in future survey articles.

\section{RIGHT TO WORSHIP AND FREEDOM OF RELIGION}

In Solomon v. State, ${ }^{8}$ the court of appeals rejected a defendant's argument that

2. Eighteen topics were addressed in 2014, Jon Laramore \& Daniel E. Pulliam, Indiana Constitutional Developments: Small Steps, 47 IND. L. REV. 1015, 1042 (2014); ten were addressed in 2015, Jon Laramore \& Daniel E. Pulliam, Developments in Indiana Constitutional Law: A New Equal Privileges Wrinkle, 48 IND. L. REV. 1223, 1240 (2015); fourteen were addressed in 2016, Scott Chinn \& Daniel E. Pulliam, Minimalist Developments in Indiana Constitutional Law - Equal Privileges Progresses Slowly, 49 IND. L. REV. 1004, 2021 (2016); twelve topics covered in 2017, Scott Chinn \& Daniel E. Pulliam, Emerging Federal Reliance-Continued State Constitutional Minimalism: Indiana State Constitutional Law Summaries-2015-2016, 50 IND. L. REV. 1216, 1238 (2017); ten topics were covered in 2018, Scott Chinn \& Daniel E. Pulliam, Emerging Federal Reliance-Continued State Constitutional Minimalism: Indiana State Constitutional Law Summaries-2016-2017, 51 IND. L. REv. 992, 993 (2018); thirteen were addressed in 2019, Scott Chinn, Daniel E. Pulliam, and Elizabeth M. Little, Stuck in a Rut or Merely within the Lines? Indiana State Constitutional Law Summaries-2017-2018; 52 IND. L. REV. 659 (2019); and fifteen were addressed in 2020, infra §§ I-XV.

3. Loretta H. Rush \& Marie Forney Miller, A Constellation of Constitutions: Discovering \& Embracing State Constitutions As Guardians of Civil Liberties, 82 ALB. L. REv. 1353, 1354 (2019).

4. Id.

5. $I d$.

6. Id. at 1382 .

7. $I d$.

8. Solomon v. State, 119 N.E.3d 173, 175 (Ind. Ct. App. 2019), trans. denied, 127 N.E.3d 
the statute criminalizing possession of marijuana violated his rights under Article 1, Section 1 of the Indiana Constitution. Because marijuana "brings happiness to some people" by alleviating medical conditions or through simple recreation, the defendant argued that his conduct of possessing a single marijuana blunt while not driving or impacting others violated his Article I, Section 1 rights 9

The court's decision did not analyze the broad language of the provision;

WE DECLARE, That all men are created equal; that they are endowed by their CREATOR with certain unalienable rights; that among these are life, liberty and the pursuit of happiness; that all power is inherent in the PEOPLE; and that all free governments are, and of right ought to be, founded on their authority, and instituted for their peace, safety, and well-being. For the advancement of these ends, the People have, at all times, an indefeasible right to alter and reform their government. ${ }^{10}$

Rather, the decision rested on the lack of caselaw supporting the defendant's position. At the same time, the decision seemed to cast doubt on the viability of older cases relying on Section 1 to provide liberty of consumption, contract, and vocation. Although not adopting it, the court made extensive note of the State's argument that these cases had been discredited and that Section 1 should no longer be interpreted to provide "judicially enforceable rights." 11

Apart from finding the defendant waived his argument by not arguing it in the trial court, the court of appeals refused to reverse the conviction because the Indiana legislature has not repealed its statute prohibiting the possession of marijuana. ${ }^{12}$ "The extent to which [defendant]'s possession of marijuana under these circumstances constituted a criminal offense is a legislative determination and not a judicial one."13

\section{FREEDOM OF THOUGHT AND SPEECH}

In Stone v. State, ${ }^{14}$ the court of appeals rejected the defendant's argument that his harassing telephone calls were protected under Article I, Section 9 of the Indiana Constitution. Article I, Section 9 provides, "No law shall be passed, restraining the free interchange of thought and opinion, or restricting the right to speak, write, or print, freely, on any subject whatever; but for the abuse of that right, every person shall be responsible." ${ }^{15}$ In determining whether there has been a violation of Article I, Section 9, courts employ a "two-step inquiry," first determining "whether state action has restricted a claimant's expressive activity;

225 (Ind. 2019).

9. Id. at 175 .

10. Id. at 174 (quoting IND. Const. art. I, § 1).

11. Id. at 176 .

12. Solomon, 119, N.E.3d at 178.

13. Id.

14. Stone v. State, 128 N.E.3d 475 (Ind. Ct. App. 2019).

15. Id. at 482 (quoting IND. Const. art. I, § 9). 
and second, [] whether the restricted activity constituted an abuse of the right to speak." 16

For the first step, the court of appeals considered whether defendant's speech "was protected political speech." 17 "[W] here speech is at least in part not germane to a public issue, a trier of fact may find the speech as a whole not protected by Article I, Section 9." 18 Here, the court of appeals found that the defendant's speech "was not unambiguously political as a matter of law." 19 Defendant's phone calls centered around an alleged government conspiracy, that a reasonable fact-finder could find are "ambiguous . . . , not political." ${ }^{20}$ Because a reasonable fact-finder could find the defendant's speech as not political, that ended the inquiry - the defendant's speech is not protected under Article I, Section 9. ${ }^{21}$

\section{PRIVILEGES AND IMMUNITIES}

In Richardson's RV, Inc. v. Indiana Department of State Revenue, ${ }^{22}$ the Indiana Supreme Court found that the Indiana Department of Revenue charging an Indiana RV dealership state sales tax for RVs sold to out-of-state customers did not violate the Equal Privileges and Immunities clause of Ind. Const. Article I, Section $23 .^{23}$ The dealership attempted to avoid paying state sales tax by taking the RVs sold to out-of-state customers to Michigan before handing the keys to the customer. The court found that sales tax was owed on these sales because the dealership structured the out-of-state deliveries solely to avoid sales taxes with no legitimate business purpose. ${ }^{24}$ The court also found Article I, Section 23 inapplicable because "individuals are afforded equal protection guarantees, not activities." 25

In Himsel v. Himsel, ${ }^{26}$ the court of appeals rejected the plaintiffs' argument that Indiana Code section 32-30-6-9, the Right to Farm Act (the "RTFA"), violates Article I, Section $23 .{ }^{27}$ In addition to their constitutional arguments,

16. Stone, 128 N.E.3d at 482 (internal quotations omitted).

17. Id.

18. Id. at 483 (internal citations omitted).

19. Id.

20. Id. (internal citations omitted).

21. By contrast, the Court's analysis under the First Amendment of the U.S. Constitution presumed that the calls constituted the use of a public forum because the calls were made to the Indiana Statehouse. Yet, the Court nevertheless concluded that the government regulation was permissible because it was content neutral and justified without reference to the regulated speech's content.

22. Richardson's RV, Inc. v. Ind. Dep't of State Revenue, 112 N.E.3d 192 (Ind. 2018).

23. Id. at 197, n.7.

24. Id. at 194.

25. Id. at 197, n.7 (quoting RDI/Caesars Riverboat Casino, LLC v. Ind. Dep't of State Revenue, 854 N.E.2d 957, 962 n.4 (Ind. Tax Ct. 2006)) (emphasis added).

26. Himsel v. Himsel, 122 N.E.3d 935, 948-49 (Ind. Ct. App. 2019).

27. This case has three constitutional issues. The others are discussed infra in Parts V and IX. 
plaintiffs alleged that their use, enjoyment, and value of their homes were negatively impacted by "noxious odors and airborne emissions" from the nearby concentrated animal feeding operation ("CAFO"). ${ }^{28}$ But the RTFA limits circumstances where agricultural operations, including CAFOs, may be subject to nuisance claims.

When a statute affords unequal treatment to different classes of persons, courts apply a two-part test to determine whether a statute violates Article I, Section 23: (i) "the disparate treatment accorded by the legislation must be reasonably related to inherent characteristics which distinguish the unequally treated classes" and (ii) "the preferential treatment must be uniformly applicable and equally available to all persons similarly situated." ${ }^{29}$ The plaintiffs here were unable to meet this test.

With respect to the first part of the test, the plaintiffs asserted that the RTFA splits residents in two groups: (1) farmers and (2) non-farmers, affording the right of farmers to sue those in either group for nuisance, while permitting non-farmers only to sue other non-farmers for nuisance. ${ }^{30}$ While the court of appeals recognized the preferential treatment afforded to farmers under the RTFA, the court of appeals founds that the rationale behind the RTFA "provides a reasonable basis for treating farmers differently than their non-farming neighbors." ${ }^{11}$ The RTFA provides that the rationale behind the statute is "to reduce the loss to the state of its agricultural resources by limiting the circumstances under while agricultural operations may be deemed to be a nuisance." ${ }^{32}$

With respect to the second part of the test, the court found "that the RTFA's preferential treatment is uniformly and equally available to all agricultural operations and although agricultural operations are treated differently under the RTFA than non-agricultural operations, the two are not similarly situated and the express intent of the RTFA is to protect agricultural land." court held the RTFA not to violate Article I, Section 23.

\section{SEARCH AND SEIZURE}

In Wright v. State, ${ }^{34}$ the Indiana Supreme Court adopted the attenuation doctrine to allow for the admissibility of evidence derivative from an illegal search. ${ }^{35}$ Federal authorities obtained a search warrant of the defendant's residence based on an IP address located there known to access child

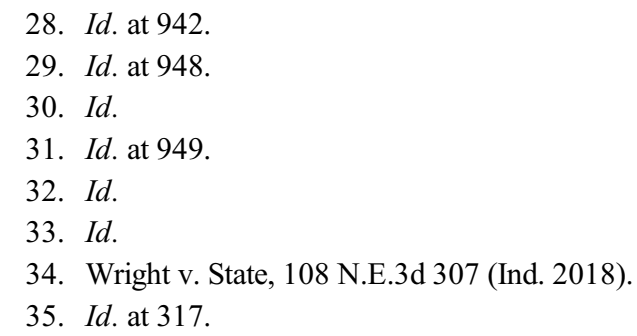


pornography websites. ${ }^{36}$ Upon arrival, authorities realized that the home had upstairs and downstairs units. ${ }^{37}$ During the search of the upstairs and seizure of the computer, the agent learned that all occupants shared an Internet connection. ${ }^{38}$ Rather than getting a second warrant or obtaining written consent, the agent gave the occupants of the downstairs unit, including the defendant, the option of consenting a search and then receiving their computers back immediately or leaving the residence until he obtained a second search warrant. ${ }^{39}$ But critically, the agent failed to advise the residents they could refuse to consent. ${ }^{40}$ The downstairs residents verbally consented. That weekend, the agent ran scans on the computers and found child pornography images on the defendant's computer. ${ }^{41}$

The agent returned the equipment and asked to speak with Wright with the option of speaking inside or outside the house. ${ }^{42}$ Wright chose outside and the two went to the agent's car where, the agent told the defendant the car was unlocked, he could leave at any time, and he was not under arrest. ${ }^{43}$ The agent then asked him about the search results, and the defendant confirmed that he had searched for child pornography and that he had also had sexual contact with two of the children living in the home. ${ }^{44}$ The agent then called local police, who placed him under arrest. ${ }^{45}$ The trial court denied the defendant's motion to suppress the evidence and he was found guilty at a bench trial of four felony counts of child molesting and sexual contact with the minors. He received a sixty-year prison sentence. ${ }^{46}$

On appeal, the defendant's convictions were reversed on the basis that the defendant's confessions to the agent were improperly admitted and rejecting the attenuation doctrine ${ }^{47}$ The defendant's statements to the agent were derivative of the illegal search and seizure of the computers and thus fruit of the poisonous tree. $^{48}$

The Indiana Supreme Court disagreed. ${ }^{49}$ The exclusionary rule was a judicially created rule to deter police misconduct and secure the rights of Hoosiers. ${ }^{50}$ The text of Article I, Section 11 does not expressly mandate the

36. Id. at 311 .

37. Id.

38. Id.

39. Id.

40. Id.

41. Id. at 311-12.

42. Id. at 312 .

43. Id.

44. Id.

45. Id.

46. Id. at 312-13.

47. Id. at 313 .

48. $I d$.

49. Id.

50. Id. at 313-14. 
result. ${ }^{51}$ Indiana courts had recognized two exceptions to the rule: the good faith exception - where police acted on "objectively reasonable reliance" on an invalid search warrant - and the "new-crime" exception - where the defendant commits a new crime in response to an illegal search or seizure. ${ }^{52}$ The attenuation doctrine, accepted by Fourth Amendment doctrine, does not suppress the fruit of the poisonous tree if it is not obtained by the exploitation of the primary illegality. ${ }^{53}$ The court found that adopting the attenuation doctrine would not undermine the exclusionary rule's purpose. ${ }^{54}$ Excluding derivative evidence secured remote in time, place, or agency would not deter police misconduct. ${ }^{55}$ Examining the causal chain between the illegality and the evidence subject to exclusion places a reasonable limit on the exclusionary rule. ${ }^{56}$ The "concept fits nicely within" the court's jurisprudence, while also holding that Indiana's doctrine would be parallel to the federal doctrine to the extent it examines the totality of the circumstances. ${ }^{57}$

As applied to this defendant, the court found that the fact a weekend passed between the illegal search and seizure gave the defendant time to consider whether he would confess. ${ }^{58}$ The defendant was not arrested and volunteered the information. ${ }^{59}$ And the illegal search was not a flagrant disregard of the defendant's rights. ${ }^{60}$ Thus, the statements were deemed admissible and the defendant's convictions were affirmed. ${ }^{61}$

In Dycus v. State, ${ }^{62}$ the Indiana Supreme Court held that law enforcement does not have to advise a person of their rights before obtaining consent to a field sobriety tests or blood draws. ${ }^{63}$ Pirtle v. State ${ }^{64}$ held in 1975 that the Indiana Constitution requires law enforcement to advise persons of their rights before obtaining their consent to search their homes or vehicles. ${ }^{65}$ Noting that the "Pirtle" right has no federal counterpart and that it is a protection that goes beyond the U.S. Constitution, the court readily found that no such warning is required before law enforcement ask for consent to perform such exams. ${ }^{66}$

The court rejected a line of analysis from the court of appeals that analyzed

51. Id. at 313 .

52. Id. at 314 .

53. Id.

54. Id. at 316 .

55. Id.

56. Id.

57. Id. at 317 .

58. Id. at 319 .

59. Id.

60. Id.

61. Id. at 320 .

62. Dycus v. State, 108 N.E.3d 301 (Ind. 2018).

63. Id. at 302 .

64. Pirtle v. State, 323 N.E.2d 634 (1975).

65. Dycus, 108 N.E.3d at 302.

66. Id. 
the question based on intrusiveness. ${ }^{67}$ The scope and breadth provided guidance but whether a search was more or less intrusive did not factor into whether the Indiana Constitution required an advisement before consent. ${ }^{68}$ The court also rejected an examination of a person's legitimate expectations of privacy or the reasonableness of the intrusion. ${ }^{69}$ Those questions go to whether a warrant is required. ${ }^{70}$ The question of consent went to whether the consent was truly voluntary as "consent to certain weighty intrusions carries a great risk of involuntariness." " When a person gives up their right to the protections of a search warrant and gives "carte blanche to search for unspecified evidence," such as a home or a vehicle, the justification supporting the Pirtle admonition is high. ${ }^{72}$

Such risks, according to the court, were not present with a field sobriety test or a blood draw. ${ }^{73}$ The procedure involves an examination of arms, mouths, and noses and procedures that take place in dark rooms that feed into a system that takes measurements in an objective manner. ${ }^{74}$ Unlike the search of a vehicle or a home, the court did not see a strong likelihood of such exams turning up inculpatory evidence and the scope of the exams are narrow: oral thermometers, mouth and nasal cavity exams, and blood pressure checks. ${ }^{75}$ Thus, these searches are sufficiently specific to eliminate the risk of involuntary consent that is present with a home or a vehicle. ${ }^{76}$

In State v. Bouye, ${ }^{77}$ the Indiana court of appeals reversed a trial court's suppression of evidence discovered during a traffic stop based on license plate check. ${ }^{78}$ The license plate check revealed that the plates were registered to a different vehicle, but the defendant's wife testified at trial that she had transferred the plate's registration more than a month earlier. ${ }^{79}$ During the stop, the officer discovered marijuana and noticed the defendant was possibly intoxicated. ${ }^{80}$ The trial court ordered the evidence of the marijuana and the possible intoxication suppressed because of the "breakdown somewhere" in the officer's determination of reasonable suspicion that the vehicle's plates were improperly registered ${ }^{81}$

The court of appeals held the fact that the defendant had evidence that the vehicle was properly registered - and that the license plate check was somehow

67. Id. at 306 .

68. Id.

69. Id.

70. Id.

71. Id.

72. Id.

73. Id. at 307.

74. Id.

75. Id.

76. Id.

77. State v. Bouye, 118 N.E.3d 22 (Ind. Ct. App. 2019).

78. Id. at 24 .

79. Id.

80. Id.

81. Id. 
faulty—was "beside the point." ${ }^{\$ 2}$ Citing 2008 Indiana Supreme Court precedent, the court recognized that the Fourth Amendment's reasonable suspicion standard mirrors the standard Indiana courts use under Article I, Section $11 .^{83}$ Thus, the actuality of the violation was "irrelevant to the constitutionality of the stop. What matters is whether the officer had a reasonable suspicion that a violation had occurred." ${ }^{184}$ Here, based on the results of the license plate check, the stop was constitutional under Article I, Section $11{ }^{85}$ Reliance on the State database was sufficient and did not require a full investigation of the vehicle before stopping the vehicle. ${ }^{86}$

In Johnson v. State, ${ }^{87}$ the defendant challenged the admission of evidence obtained by location information acquired from the defendant's cell phone carrier that led to a search warrant, which allowed law enforcement to find him in his girlfriend's apartment with bullet cartridges like those found at the crime scene. ${ }^{88}$ The government obtained the defendant's cellular tracking information under a State statutory exception to the warrant requirement based on "exigent circumstances." ${ }^{\circ 9}$ Because the statute did not define "exigent circumstances," the court relied on case law determinations that justified warrantless entry where the suspect is fleeing, incriminating evidence is about to be destroyed, hot pursuit of cares, or to prevent injury. ${ }^{90}$ Here, the court found exigent circumstances not based on any of these recognized exceptions but on the finding of a victim's body and a cell phone with that body showing an outgoing call to the defendant's cell phone and text messages indicating drug trafficking activity. ${ }^{91}$ Based on this, law enforcement sought the defendant's cell location and a search warrant for Johnson's mother's address. ${ }^{92}$ But based on the cell-location tracking information, law enforcement knew the defendant's new location at his girlfriend's house. ${ }^{93}$

The State justified the warrant based on the recency of the homicide and the understanding that those who recently committed a homicide are a danger to the community. ${ }^{94}$ The court agreed. ${ }^{95}$ Exigent circumstances, under this court's decision, now exist to obtain cell location data for any cell phones found on

\section{Id. at 25 .}

83. Id.; See Campos v. State, 885 N.E.2d 590, 596 (Ind. 2008).

84. Bouye, 118 N.E.3d at 25.

85. Id.

86. Id. at 26 .

87. Johnson v. State, 117 N.E.3d 581, 583-85 (Ind. Ct. App. 2018), trans. denied, 2019 WL 1284375 (Ind. Mar. 14, 2019).

88. Id. at 583 .

89. IND. CODE $§ 35-33-5-12(a)(2)(2020)$.

90. Johnson, 117 N.E.3d at 584 .

91. Id. at 584-85.

92. Id. at 585 .

93. Id.

94. Id. (internal citation omitted).

95. Id. 
homicide victims under "exigent circumstances." ${ }^{96}$ In support of this holding on exigent circumstances, the court noted in a footnote that the recent decision of Carpenter $v$. United States, ${ }^{97}$ did not apply because it involved real-time cell site location information and this case involved "ping" data. ${ }^{98}$ Further, Carpenter recognized that exigent circumstances may justify warrantless searches. ${ }^{99}$ Notably, the court did not analyze whether Indiana's protections against warrantless seizures might apply differently even though it noted the general principle. ${ }^{100}$

In Brown v. State, ${ }^{101}$ the court of appeals found that the above-discussed Pirtle $^{102}$ advisement is unnecessary when law enforcement has a search warrant. ${ }^{103}$ Under Pirtle v. Indiana, a citizen's consent to search is invalid under Article I, Section 13 unless the individual subject to the search is advised of their right to counsel. ${ }^{104}$ Here, law enforcement executed a search warrant that covered any "closed container" on the premises subject to the search. ${ }^{105}$ As a preliminary matter, the defendant here told law enforcement about the safe and its combination; there was no evidence that law enforcement asked for that information. ${ }^{106}$ Further, the Pirtle doctrine was "intended to help citizens in custody preserve the very same constitutional protections that are preserved by the search warrant requirement." ${ }^{107}$ Thus, once law enforcement has obtained a search warrant for the safe, "those constitutional protections cannot be at risk."108

In Hardin v. State, ${ }^{109}$ the court of appeals held that surveillance-based information, showing that the defendant was dealing methamphetamine, justified the search under Article I, Section 11 of the Indiana Constitution. ${ }^{10}$ Wiretap communications showed that Hardin was discussing methamphetamine deals in an area near Martinsville. Based on these wiretaps, law enforcement obtained a search warrant for a residence. ${ }^{111}$ At the residence, the officers found methamphetamine-related items, including a pound of methamphetamine and

96. $I d$.

97. Carpenter v. United States, 138 S. Ct. 2206 (2018).

98. Id. at 585 n. 2 .

99. Id.

100. Id.

101. Brown v. State, 118 N.E.3d 763 (Ind. Ct. App.), trans. denied, 124 N.E.3d 44 (Ind. 2019).

102. Pirtle v. State, 323 N.E.2d 634, 640 (1975).

103. Brown, 118 N.E.3d at 770.

104. Id. at 766 n.6.

105. Id. at 765 .

106. Id. at 766 .

107. Id. at 768 .

108. Id.

109. Hardin v. State, 124 N.E.3d 117 (Ind. Ct. App. 2019).

110. Id. at 124 .

111. Id. at 119. 
$\$ 327,000$ in cash, but ultimately found 100 grams of methamphetamine in Hardin's vehicle, which was not subject to the search warrant. ${ }^{112}$

For the court's majority, the search of the vehicle was justified by the degree of concern, suspicion, and knowledge that a violation had occurred. ${ }^{113}$ But Judge Mathias dissented on the basis that a vehicle, even when on the curtilage of the property subject to the search warrant, is not subject to the search warrant. ${ }^{114}$ Although law enforcement had strong evidence that Hardin was dealing in methamphetamine, the degree of intrusion was high, and "Hoosiers regard their automobiles as private and cannot easily abide their uninvited intrusion." 115 The search warrant did not mention the curtilage, let alone the vehicle, and the burden on law enforcement to secure the vehicle and obtain another search warrant was minimal. ${ }^{116}$

In Marshall v. State, ${ }^{117}$ the supreme court held that an officer's radar indication of a vehicle speeding is sufficient reasonable suspicion for a traffic stop even when the officer fails to document that excessive speed. ${ }^{118}$ The officer's radar gave of a high-pitch tone that indicated a speeding car-the higher the pitch, the faster the car. ${ }^{119}$ The officer stopped the car, smelled alcohol, and decided to let the speeding issue go given that the defendant would have "plenty of money problems and legal problems ahead of him." ${ }^{120}$ At a deposition, though, the officer could not recall the defendant's rate of speed or the posted speed limit in that area. ${ }^{121}$ The defendant moved to suppress the evidence of the traffic stop as a violation of Article I, Section 11, and the Fourth Amendment. ${ }^{122}$

The court upheld the legality of the stop. ${ }^{123}$ Under the Indiana Constitution, the court recognized that the stop had to be reasonable under the totality of the circumstances. ${ }^{124}$ The officer had a high degree of knowledge that the defendant was speeding based on the high-pitched tone of his radar unit. ${ }^{125}$ The stop was only a "small intrusion" on the defendant's activities. ${ }^{126}$ It was the middle of the night and there was no traffic. ${ }^{127}$ The officer then almost immediately smelled the

112. Id. at 120 .

113. Id. at 124 .

114. Id. at 125 .

115. Id. at 126 (internal citations omitted) (quoting Myers v. State, 839 N.E.2d 1146, 1153 (Ind. 2005)) (Mathis, J., dissenting).

116. Hardin, 124 N.E.3d at 126.

117. Marshall v. State, 117 N.E.3d 1254, 1254 (Ind. 2019).

118. Id. at 1256.

119. Id.

120. Id. at 1256-57 (internal citations omitted).

121. Id. at 1257.

122. Id.

123. Id. at 1261 .

124. Id.

125. Id. at 1262 .

126. Id.

127. Id. 
alcohol. ${ }^{128}$ Speeding is also a legitimate, if not compelling, law enforcement need. ${ }^{129}$ Thus, the stop was lawful.

\section{OPENNESS OF COURTS}

In Small v. State ${ }^{130}$ the court of appeals reversed a conviction because the trial court improperly granted the State a continuance. ${ }^{131}$ The defendant was arrested for unlawful possession of a firearm and methamphetamine. ${ }^{132}$ The gun was found inside his motel room. ${ }^{133}$ The State sought the defendant's DNA profile, which the court granted without a hearing, and then at the initial hearing, the court granted the defendant's motion for a speedy trial under Criminal Rule 4, requiring a defendant in jail to be tried within seventy days. ${ }^{134}$ The court also rescinded its order on the DNA after the defendant objected to the motion being granted in his absence. ${ }^{135}$ The court then held a hearing on the DNA and instructed the State to file a proposed order for the court to sign. ${ }^{136}$ But the State waited forty-four days - six days before trial — to discover that the order had not been received and sought a continuance of the trial. ${ }^{137}$ The court granted the continuance and the defendant was convicted but not because of the thenobtained DNA evidence, because the DNA evidence was inconclusive. ${ }^{138}$

The court of appeals reversed based on the trial court's abuse of its discretion in continuing the trial in violation of the defendant's right to a speedy trial under the Sixth Amendment of the U.S. Constitution and Article 1, Section 12 of the Indiana Constitution - Criminal Rule 4 functions to protect both rights. ${ }^{139}$ The court of appeals recognized that the State did not have to show that the DNA evidence was critical to its case. ${ }^{140}$ It just had to show that the State was entitled to present it and the request for a continuance to obtain that evidence was reasonable. But the State's request was not reasonable. ${ }^{141}$ Waiting until days before the trial to bring the missing order to the court's attention - due to a "glitch in the Odyssey system" - could justify a modest delay, but the State waited thirtyeight days to discovery the error knowing that the case was set on a speedy trial

128. Id.

129. Id.

130. Small v. State, 112 N.E.3d 738 (Ind. Ct. App. 2018).

131. Id. at 739 .

132. Id.

133. Id.

134. Id. at 739-40.

135. Id. at 740.

136. Id.

137. Id.

138. Id.

139. Id. at 741-42.

140. Id. at 742 .

141. Id. 
calendar. ${ }^{142}$ The State also failed to take steps to attempt to expedite the DNA testing. ${ }^{143}$ Thus, the State's actions "suggest inattentiveness, rather than prudence" and a failure "to closely monitor the progress of a speedy trial case." 144

In Hendricks County. v. Green, ${ }^{145}$ the court of appeals held that court employees, including probation officers, are entitled to cash out unused payed time off under the court's employee manual. ${ }^{146}$ Because the judiciary is an independent branch of the government and is constitutionally obligated to keep the courts open for the administration of justice, the judiciary must have coequal power as the executive branch. Courts must also remain open under the constitution. Because a probation officer is a court-related function, the "courts have the corresponding constitutional power to pay probation officers at a level sufficient to attract and maintain qualified personnel." ${ }^{147}$ Thus, when the General Assembly assigned the Judicial Conference the job of establishing rules and regulations applicable to probation officers, those rules addressing salary overruled any other State law applicable to county employees. ${ }^{148}$ Even though the money came out of the municipality's treasury, unused payed time off constituted deferred compensation. ${ }^{149}$ The probation officers were thus entitled to cash payouts of unused payed time off in accordance with the employee manual. ${ }^{150}$

In In re D.H., the court of appeals held that the mishandling of a case terminating her rights as a mother denied her due process. ${ }^{151}$ The mother had repeatedly reported instances of physical abuse by the father. ${ }^{152}$ The father was then sent to prison for making methamphetamine in the home but was then released and moved back in with the family. ${ }^{153}$ Then both parents tested positive for illegal substances and the children were removed from the home for failing to keep a safe house, drug and alcohol use, and domestic violence. ${ }^{154}$ The parents then started a series of counseling and treatment programs. ${ }^{155}$ Yet the father continued to abuse the mother, around the children, and then one of the children told the mother that the father had sexually abused her a few days earlier. ${ }^{156}$ The

142. Id. at 743 (internal citations omitted).

143. Id. at 744 .

144. Id. at 745 .

145. Hendricks Cnty. v. Green, 120 N.E.3d 1118 (Ind. Ct. App. 2019).

146. Id. at 1121 .

147. Id. at 1122 (see Noble Cnty. Council v. State ex rel. Fifer, 125 N.E.2d 709, 714-17 (Ind. 1955).

148. Id. at $1122-23$.

149. Id. at 1123 .

150. Id. at 1124 .

151. 119 N.E.3d 578, 586, 591 (Ind. Ct. App. 2019) (opinion adhered to as modified on reh'g sub nom); D.H. v. Indiana Dep't of Child Servs., 122 N.E.3d 832. 832 (Ind. Ct. App. 2019).

152. Id. at 581 .

153. Id.

154. Id.

155. Id.

156. Id. 
mother then cooperated with an investigation into the allegation of sexual abuse but stated that she did not believe the allegation was true. The Department of Child Services then sought to terminate both parent-child relationships, which the trial court granted. ${ }^{157}$

The court of appeals reversed because the family case manager failed to develop a family service plan, assess the strengths and needs of the child and family, and work with the family and its counseling team to assist with the provision of counseling and other services. ${ }^{158}$ The case manager knew nothing about the mother's service needs or compliance with those services but nevertheless sought to terminate her parental rights. ${ }^{159}$ The mother had stopped living with the father and did not have a visitation plan that would result in the children interacting with the father. These procedural irregularities in the case created a risk that the filing of the petition to terminate the mother's parental rights violated her due process rights. ${ }^{160}$

Notably, the mother did not identify which constitution her claim arose under - the federal Due Process Clause or the state Due Court of Law Clause. In a footnote, the court reminded that procedural due process analysis under both constitutions is the same under Cooper v. State. ${ }^{161}$

In Harrison v. Knight ${ }^{162}$ the court of appeals found that an individual held in jail on parole violations - but not formally arrested on any charges - potentially triggered a violation of Article 1, Section 12. ${ }^{163}$ The defendant pled guilty to unlawful possession and received a twenty-year prison sentence. ${ }^{164} \mathrm{He}$ was released nine years later, committed a new offense, apprehended in South Carolina, and placed in custody on parole violations. ${ }^{165} \mathrm{He}$ then signed a written "waiver of preliminary hearing" document listing his alleged parole violations but pled not guilty at the same time. ${ }^{166}$ While held in custody, he sought a speedy trial, but the trial court denied the motion as he had not been arrested on new charges but was being held on parole violations. ${ }^{167}$ The defendant then sought habeas corpus relief.

The court of appeals found without new charges filed against the defendant, and his written waiver of his preliminary hearing, had him "incarcerated with no end in sight" because the speedy trial rights were not triggered. ${ }^{168}$ The court credited the defendant's appellant counsel with recognizing that he was "up a

157. $I d$. at 583 .

158. Id. at 590 .

159. Id.

160. Id. at 591.

161. Id. at 591 n. 16.

162. Harrison v. Knight, 127 N.E.3d 1269 (Ind. Ct. App. 2019).

163. Id. at 1270 .

164. Id.

165. Id.

166. Id.

167. Id. at 1270-71.

168. Id. at 1272 . 
creek without a paddle." ${ }^{169}$ The State took the position that the defendant could be lawfully in prison until his twenty-year sentence expired without any determination as to his parole violation. ${ }^{170}$ The court rejected the idea, though, that the State did not have any burden to establish a parole violation. ${ }^{171}$ The defendant's purported waiver of his right for a hearing on the parole violation would contradict Article 1, Section 12: "All courts shall be open; and every person, for injury done to him in his person, property, or reputation, shall have remedy by due course of law." 172

In Himsel v. Himsel, ${ }^{173}$ the court of appeals held that the RTFA does not violate Article 1, Section 12 of the Indiana Constitution. ${ }^{174}$ In their motion for summary judgment, plaintiffs alleged that the RTFA is unconstitutional because it prevents them from being able to enforce property rights in their homes. In addition to their constitutional arguments, plaintiffs alleged that their use, enjoyment, and value of their homes were negatively impacted by "noxious odors and airborne emissions" from the nearby CAFO. ${ }^{175}$ But the RTFA limits circumstances where agricultural operations, including CAFOs, may be subject to nuisance claims. ${ }^{176}$

The court of appeals found this restriction in RTFA to be rational. ${ }^{177}$ "Our Supreme Court has made clear that [the Open Courts Clause] 'does not prohibit all conditions on access to the courts, but it does prevent the legislature from arbitrarily or unreasonably denying access to the courts." 178 "The Open Courts Clause does not require the substantive law to provide a remedy, and individuals have no vested or property right in any rule of common law ... Accordingly, 'the General Assembly can make substantial changes to the existing law without infringing on citizen rights." ${ }^{179}$ Because the plaintiffs never had a valid nuisance claim due to the facts underlying their claim occurring after the RTFA went into effect, the court of appeals found their claim to be barred and the limitations imposed on the plaintiffs' claims under the RTFA to not violate Article 1, Section $12 .^{180}$

169. Id. at 1273 (internal citations omitted).

170. Id.

171. Id.

172. Id. (quoting IND. Const. art. $1 \S 12$ ).

173. Himsel v. Himsel, 122 N.E.3d 935, 946 (Ind. Ct. App. 2019).

174. This case has three constitutional issues. The others are discussed in $\S \S$ III and IX.

175. Id. at 942 .

176. Id.

177. $I d$. at 946 .

178. Id. at 945-46 (quoting KS \& E Sports v. Runnels, 72 N.E.3d 892, 905 (Ind. 2017)).

179. Id. at 946 (quoting McIntosh v. Melroe Co., 729 N.E.2d 972, 978 (Ind. 2000)).

180. Id. 


\section{RIGHTS OF THE ACCUSED AND VICTIMS}

In Hudson v. State, ${ }^{181}$ the court of appeals held that a failure to advise a defendant charged with a misdemeanor of the consequences of failing to demand a jury trial, or the rules' specific requirements for doing so, violated the constitutional right to a jury. ${ }^{182}$ The defendant was charged with battery resulting in bodily injury, a Class A misdemeanor. ${ }^{183}$ The trial court explained the right to a jury "if you want one" at the initial hearing but for the next few months, no additional advisement was provided. ${ }^{184}$ The prosecutor and public defendant signed an "off record request" form seeking a bench trial, but the defendant did not sign it. ${ }^{185}$ The defendant then expressed concern with his public defender. ${ }^{186}$ Yet the trial court simply assured him the trial would be done "fully and fairly," and the defendant was convicted and sentenced to 365 days with 359 suspended. ${ }^{187}$

The court found that although the rules do not require formal notice of a waiver of a jury trial, Article 1, Section 13 guarantees the right without differentiation between felonies and misdemeanors. ${ }^{188}$ Rule 22 of the Indiana Rules of Criminal Procedure requires the defendant to demand in writing the jury trial, but that waiver must be done in a knowing, intelligent, and voluntary means. ${ }^{189}$ And here, that did not happen. The record did not show that the court advised the defendant of failing to demand a jury trial or the specific requirements of doing so. ${ }^{190}$

\section{ARTICLE $1, \S 18$ - PENAL CODE FoUNDED ON REFORMATION}

In State v. Stafford, ${ }^{191}$ the court of appeals held that a statutory amendment affirmed a prohibition against court amendments of a defendant's sentence that are under a fixed plea agreement. ${ }^{192}$ The defendant had pled guilty to a fixed term

181. Hudson v. State, 109 N.E.3d 1061 (Ind. Ct. App. 2018).

182. Id. at 1065 .

183. Id. at 1062 .

184. Id.

185. Id. at 1062-63.

186. Id. at 1063 .

187. Id.

188. Id.

189. Id. at 1063-64.

190. In Bradtmiller v. State, 113 N.E.3d 255, 257 (Ind. Ct. App. 2018), the Court came to a similar conclusion in holding that because the defendant was never advised of his right to a jury trial for a habitual-offender enhancement, his jury-trial waiver lacked "sufficient awareness of the relevant circumstances and therefore did not apply to the later-filed habitual-offender enhancement."

191. State v. Stafford, 117 N.E.3d 621 (Ind. Ct. App. 2018), trans. granted, opinion vacated, 2019 WL 1750925 (Ind. Apr. 11, 2019).

192. Id. at 622 . 
with no provision for a sentencing modification. ${ }^{193}$ Weeks after the guilty plea, the General Assembly relaxed the rules regarding modifying sentences, stating that defendants "may not waive the right to sentence modification," but still required the prosecutor's assent to amend a fixed plea agreement. ${ }^{194}$ The defendant sought, and the trial court granted, a sentencing modification based on evidence showing the defendant's rehabilitation. ${ }^{195}$ After the court of appeals affirmed the trial court, the legislature amended the statute again, prompting the Indiana Supreme Court to grant transfer and remand the case back to the court of appeals for further decision. ${ }^{196}$

The State argued that fixed plea agreements do not permit sentencing modifications without the prosecutor's approval. ${ }^{197}$ The court of appeals agreed on the basis that the legislature indicated intent not create a right to modify fixed sentences. ${ }^{198}$ Relying on a dissent of Senior Judge Rucker, the court of appeals found that the original statute created ambiguity between whether a fixed plea agreement could create the right to a sentence modification. ${ }^{199}$ Because the legislature responded to the original decision in Stafford by amending the statute to add language allowing for sentence amendments only with the prosecutor's consent, the court of appeals held that fixed plea agreements may leave "no room for modification." ${ }^{200}$ If trial courts want to avoid that result, they may simply reject "fixed sentence" plea agreements. ${ }^{201}$

Judge Baker dissented on the basis that the General Assembly's amendments were an intent to loosen the rules governing sentence modifications and in a manner in conformance with Article 1, Section 18 of the Indiana Constitution, which states that the "penal code shall be founded on the principles of reformation, and not of vindictive justice." 202 The statute included language that the defendants may not waive the right to sentencing modifications in plea agreements granting the trial court authority to modify this defendant's sentence. ${ }^{203}$ The General Assembly's later amendment, if in contravention of the original order, violated separation of powers principles in Article 3, Section 1 by retroactively voiding a court order by legislation. ${ }^{204}$

193. Id. at 623 .

194. Id. at 623-24 (quoting IND. CODE $§ 35-38-1-17$ (2014)).

195. Id. at 623 .

196. Id.

197. Id. at 622 .

198. Id.

199. Id. (see State v. Stafford, 86 N.E.3d 190, 193 (Ind. Ct. App. 2017)).

200. Id. at 626 .

201. Id.

202. Id. at 627 (quoting IND. Const. art. 1, § 18) (Baker, J., dissenting).

203. Id.

204. Id. at 628 . 


\section{DOUBLE JEOPARDY}

Indiana courts use a two-part test to determine whether the Indiana Constitution's prohibition against double jeopardy is violated. First, the courts look at whether the offenses share statutory elements, and then, whether the actual evidence used to establish a conviction on one count was also used to establish an element of a separate count.

In a series of cases, the court of appeals raised double jeopardy sua sponte, reversing multiple convictions.

In Smith v. State, ${ }^{205}$ the court of appeals sua sponte found that behavior supporting "attempted theft [was] coextensive with the behavior necessary to establish . . . criminal mischief." ${ }^{206}$ The evidence showed that the defendant had cut the catalytic converter on a car he did not own. ${ }^{207}$ This was the only evidence that the defendant had damaged the car - the basis for the criminal mischief conviction. ${ }^{208}$ The court thus ordered the criminal mischief conviction vacated. ${ }^{209}$

In Ervin v. State, ${ }^{210}$ the court of appeals again sua sponte found that pointing a firearm and criminal recklessness constituted a double jeopardy violation. ${ }^{21}$ The defendant was charged with (1) creating a substantial risk of bodily injury by shooting a firearm into a vehicle and (2) intentionally pointing a firearm at the same person. ${ }^{212}$ There was nothing in the jury instructions establishing that the gun was pointed multiple times. ${ }^{213}$ And the evidence a trial was inconsistent with what the defendant did as he approached the vehicle. Although the jury could have come to a conclusion that there were multiple instances of gun pointing, the prosecutor in closing arguments described the same incident of gun pointing to establish both counts. ${ }^{214}$ Thus, there was a reasonable possibility that the jury used the same incident to establish both counts. ${ }^{215}$

205. Smith v. State, 114 N.E.3d 540 (Ind. Ct. App. 2018).

206. Id. at 544 .

207. Id. at 542 .

208. Id. at 544-45.

209. Id. at 545 .

210. Ervin v. State, 114 N.E.3d 888 (Ind. Ct. App.) trans. denied, 123 N.E.3d 132 (Ind. 2019).

211. Id. at 893-94.

212. Id. at 893 .

213. Id.

214. Id. at 894 .

215. Similarly, in Powell v. State, 127 N.E.3d 1280 (Ind. Ct. App.), trans. granted, opinion vacated, 134 N.E.3d 1017 (Ind. 2019), the court of appeals vacated one of two convictions for felony conviction for attempted murder because the State's evidence constituted the defendant shooting at a car five times causing injury to only one of the vehicle's three occupants. See id. Because it was possible some of the evidence used to prove the attempted murder of one occupant could have been used to prove attempted murder of the others, the Court vacated one of the two felony attempted murder convictions. See id. 
In Gary v. State, ${ }^{216}$ the court of appeals held that convictions for intimidation and attempted murder violated the defendant's right to be free of double jeopardy under the actual evidence test. ${ }^{217}$ The State presented evidence that the defendant pointed a gun at a police officer who was taking cover behind his police-issued truck. ${ }^{218}$ The defendant then fired the gun, hitting the license plate of the officer's vehicle. $^{219}$ The defendant continued pointing the gun at the officer until it jammed, and the officer poised to return fire, prompting the defendant to surrender. ${ }^{220}$ Because the jury could have used all this evidence to prove intimidation and attempted murder, the court vacated the conviction for intimidation. $^{221}$

For charges obtained by grand jury indictment, where the prosecutor conflated a single act as justification for separate counts of neglect, the court of appeals vacated one of the convictions because the prosecutor failed to distinguish separate acts to justify each count in closing arguments in Shultz v. State. ${ }^{22}$ The grand jury indictments failed to specify distinguishing facts and the jury instructions tracked that same vague language. ${ }^{223}$ Thus, the jury had no written instruction to allow it to make separate factual determinations supporting the elements of each charge. The prosecutor's closing argument repeatedly mentioned the same act - asphyxiation - to support both charges of neglect. ${ }^{24}$ Because this violated the defendant's double jeopardy rights, the court vacated the lesser count and ordered resentencing. ${ }^{225}$

216. Gary v. State, 124 N.E.3d 90 (Ind. Ct. App. 2019).

217. Id. at 95 .

218. Id. at 92 .

219. Id.

220. Id.

221. Id. at 95 .

222. Shultz v. State, 115 N.E.3d 1280, 1284 (Ind. Ct. App. 2018).

223. Id.

224. Id.

225. Id. at 1286-87. Similarly, in Johnston v. State, 126 N.E.3d 878, 890 (Ind. Ct. App. 2019), the court of appeals vacated a disorderly conduct conviction in part because the prosecutor failed to delineate which acts related to the specific counts in closing arguments and the charging document and jury instructions failed to specify which acts applied to which specific counts. And again, in Springfield v. State, 116 N.E.3d 1160, 1163, 1165 (Ind. Ct. App. 2018), reh'g denied (Mar. 12, 2019), opinion aff'd in part, vacated in part, 124 N.E.3d 610 (Ind. 2019), trans. granted, opinion vacated, 129 N.E.3d 780 (Ind. 2019), the court of appeals vacated a conviction for possession of a firearm as a serious violent felon where the prosecutor argued in closing arguments that it could use one conviction to enhance a separate crime involving the same factual scenario. In Wadle v. State, 120 N.E.3d 253, 258-59 n.5 (Ind. Ct. App. 2019), trans. granted, opinion vacated, 129 N.E.3d 778 (Ind. 2019), the Court of Appeals reversed under the common law double jeopardy test based, in part, on the prosecutor's argument at closing argument that failed to distinguish the evidence supporting multiple convictions. 


\section{TAKINGS}

In Himsel v. Himsel, ${ }^{226}$ the court of appeals held that the odor emitted into the plaintiffs' residential property from a nearby CAFO was not a taking under Article 1, Section 21 of the Indiana Constitution. ${ }^{227}$ The court of appeals rejected the plaintiffs' argument that the odor emitted from a nearby CAFO effected a regulatory taking. ${ }^{228}$

To effect a regulatory taking, the regulation must "deprive[] an owner of all or substantially all economic or productive use of his or her property." ${ }^{229}$ To meet this test, the court considers "the economic impact of the regulation on the property owner, the extent to which the regulation has interfered with distinct investment-backed expectations, and the character of the government action."230

Here, the court of appeals found that the plaintiffs failed to meet this test. ${ }^{231}$ The plaintiffs failed to show that they have been "deprived of all or substantially all economic or productive use of their properties" because (i) the plaintiffs' properties "retained significant economic value" even with the nearby CAFO; (ii) the plaintiffs continued to reside in their properties, "making valuable use of their properties;" and (iii) plaintiffs failed to allege any "distinct, investment-backed expectations" that have been frustrated by the CAFO. ${ }^{232}$ Finally, the court noted that although the plaintiffs' property rights seem to be affected by the CAFO that has been built under the protections of RTFA, there has been no physical invasion of the plaintiffs' properties and the plaintiffs "cannot dispute that the [RTFA] is reasonably related to the promotion of the common good." 233

\section{Ex POST FACTO LAWS}

In State v. Kirby, ${ }^{234}$ the court of appeals reversed the trial court's entry of declaratory judgment declaring that the unlawful entry statute, Ind. Code $\S 35-42$ 4-14(b), is an unconstitutional ex post facto law as applied to the defendant. In 2010, the defendant pleaded guilty to child solicitation. As part of his probation, he was not permitted to enter school premises, but he received an exception for his son's activities. In 2015, the General Assembly amended the statute making it a Level 6 felony for a "serious sex offender" to knowingly enter school property. ${ }^{235}$ The defendant challenged the application of the statute to him by

226. Himsel v. Himsel, 122 N.E.3d 935, 946-48 (Ind. Ct. App. 2019).

227. This case has three constitutional issues. The others are discussed in $\S \S \mathrm{III}$ and V.

228. Id. at 947 .

229. Id. (internal quotations omitted).

230. Id. (internal quotations omitted).

231. Id.

232. Id. at $947-48$.

233. Id. at 948 .

234. State v. Kirby, 120 N.E.3d 574, 577 (Ind. Ct. App.), trans. denied, 129 N.E.3d 775 (Ind. 2019).

235. Id. at 578 . 
seeking post-conviction relief, arguing "that he did not 'knowingly' plead guilty because he didn't know at the time of his plea that he would later be barred from school property[]" and that the statute was unconstitutional for adding punishment to his sentence. ${ }^{236}$ This case eventually made it to the Indiana Supreme Court, which found that the defendant was not able to raise his ex post facto claim in a post-conviction proceeding and must instead seek relief through a declaratory judgment action. ${ }^{237}$ This action ensued. ${ }^{238}$

"The ex post facto clause of the Indiana Constitution forbids laws that impose punishment for an act that was not otherwise punishable when it was committed." ${ }^{239}$ In determining whether a statute violates the ex post facto clause, courts apply the "intent-effects" test, looking at (i) "whether the Legislature meant the [statute] to establish civil proceedings [or punishment]," and (ii) "if the Legislature intended a nonpunitive regulatory scheme, then [courts] examine the [statute's] effects to determine whether they are in fact so punitive as to transform the regulatory scheme into a criminal penalty[.]"240

With regard to the first part of the test, when there is no legislative history and the statute at issue "does not contain a purpose statement, our Supreme Court has consistently assumed without deciding that the legislature's intent in passing the [statute] was to create a civil, regulatory, non-punitive scheme[.]"241 Assuming the purpose of the statute was to create a civil, regulatory, and nonpunitive scheme, the court of appeals moved to the second part of the test.

With regard to the second part of the test, courts apply the factors set forth in Kennedy v. Mendoza Martinez, ${ }^{242}$ :

(1) Whether the sanction involves an affirmative disability or restraint, (2) whether it has historically been regarded as punishment, (3) whether it comes into play only on a finding of scienter, (4) whether its operation will promote the traditional aims of punishment-retribution and deterrence, (5) whether the behavior to which it applies is already a crime, (6) whether an alternative purpose to which it may rationally be connected is assignable for it, and (7) whether it appears excessive in relation to the alternative purpose assigned. ${ }^{243}$

The court of appeals weighed the Mendoza-Martinez factors and concluded that the statute was not punitive as applied to the defendant and accordingly did

236. Id.

237. $I d$.

238. The trial court found that the statute was an ex post facto law as applied to defendant because defendant was allowed to attend his son's school activities prior to the enactment of the 2015 amendment.

239. Kirby, 120 N.E.3d at 578 (internal citations omitted).

240. Id. at 579 .

241. Id. (quoting McVey v. State, 56 N.E.3d 674, 680 (Ind. Ct. App. 2016)).

242. Kennedy v. Mendoza Martinez, 372 U.S. 144, 168-69 (1963).

243. Id. (quoting State v. Pollard, 908 N.E.2d 1145, 1150 (Ind. 2009)). 
not violate the ex post facto clause. ${ }^{244}$ The court of appeals found that the defendant would not incur additional costs as a result of the statute, ${ }^{245}$ defendant's situation was temporary as he only was required to register as a sex offender until 2022; defendant's prohibition from entering school property was a "collateral consequence" of defendant's conviction rather than punishment; ${ }^{246}$ the statute requires a showing of mens rea, requiring the defendant to "knowingly or intentionally" enter school property; the statute serves a valid regulatory function by eliminating a threat to school safety; ${ }^{247}$ and the determination of the defendant's guilt of the underlying criminal conviction exposed the defendant to further criminal liability. ${ }^{248}$ Finally, the court of appeals, in weighing the seventh factor most heavily, found that the purpose of the statute in protecting children from potential sexual predators outweighs defendant's interests in attending his son's school activities. ${ }^{249}$ "Presumably, being a registered sex offender is inconvenient, but it is not excessive to limit convicted sex offenders from regularly interacting with children."250

Judge Baker dissented on the basis that, upon his weighing of the seven Mendoza-Martinez factors, the statute as applied to defendant amounts to retroactive punishment and should be found unconstitutional. ${ }^{251}$ Judge Baker found that the fact that the defendant was granted specific permission to enter school property to attend his son's activities for five years prior to the enactment of the statute "clearly favors treating the effects of the [s]tatute as punitive as applied to [defendant]" and is excessive. ${ }^{252}$ This restriction on defendant was more similar to a homeowner being affected by a residency restriction than a person attempting to enter a school to take a CDL class. ${ }^{253}$ Considering the trial court explicitly permitted defendant to enter school property for his son's activities, Judge Baker found it "unreasonable to think that the trial court would have made this exception had it believed [defendant] to be a danger to society in these limited circumstances. ${ }^{254}$

Notably, during the survey period, Indiana appellate courts did not issue any published opinions on Indiana's sex offender registry, although it did address a related offense in Kirby of unlawful entry. This statute has generated a number of decisions on the issue, most notable, the Indiana Supreme Court decision in

244. Id. at 580 .

245. Id.

246. Id. at 580-81 ("[W]hen the legislature imposes restrictions on people convicted of certain crimes, those restrictions are not part of a sentence, but are collateral consequences.").

247. Id. at 582 .

248. Id.

249. Id.

250. Id. at 583 .

251. Id. at 584 .

252. Id. at 584-85.

253. Id. at 584 (comparing Pollard, 908 N.E.2d at 1145, and McVey, 56 N.E.3d at 674).

254. Id. at 585 . 
Wallace v. State, ${ }^{255}$ which held that certain applications of Indiana's Sex Offender Registration Act violated the Indiana Constitution's Ex Post Facto Clause. ${ }^{256}$

\section{RIGHT TO BEAR ARMS}

In Redington v. State, ${ }^{257}$ the court of appeals found that a trial court taking judicial notice of Robert Redington's prior red flag law proceedings, while ignoring evidence at a new hearing, would be unconstitutional. In 2012, Redington's firearms were seized by officers under Indiana's red flag law. ${ }^{258}$ The court found, after a hearing, that Redington was dangerous. Three years later, Redington filed a petition seeking the return of his firearms. During the hearing on his petition, Redington presented evidence from a psychiatrist in an attempt to get his firearms back, while the State failed to present any new evidence. Instead the State asked the court to take judicial notice of the prior proceeding. ${ }^{259}$ By taking judicial notice of the prior proceeding, the trial court found that Redington failed to meet his burden of showing that he is not dangerous.

The court of appeals reversed. ${ }^{260}$ While the court of appeals noted that Indiana's red flag law does not violate Article 1, Section 32 of the Indiana Constitution because it provides a mechanism for the impacted individual to recover their seized firearms, the court of appeals found that the trial court's reliance on the first hearing over the testimony of the psychiatrist at Redington's hearing three years later was unconstitutional. Instead of presenting evidence of Redington posing a risk of injury at his new hearing, the State relied only on the court's determination at the 2012 hearing. ${ }^{261}$ The court of appeals rejected this

255. Wallace v. State, 905 N.E.2d 371, 374 (Ind. 2009). The Wallace decision impacted an order entering summary judgment by the U.S. District Court for the Southern District of Indiana enjoining aspects of the registration requirements as violative of the federal constitutional right to travel, equal protection of the law, and the federal constitutional right against ex post facto laws. See Hope et al. vs. Commission of the Indiana Department of Correction, et al., 1:16-cv-2865-RLYTAB (S.D. Ind. July 9, 2019). According to the Court's decision, the limited constitutional floor set by the Wallace decision resulted in the violation of the federal constitutional rights of other registrants.

256. In Hope et al. v. Commissioner of the Indiana Department of Correction, et al., 1:16-cv2865-RLY-TAB (S.D. Ind. July 9, 2019), the U.S. District Court for the Southern District of Indiana found that the Sex Offender Registration Act violated a group of plaintiffs' right to travel, equal protection of the laws, and right against ex post facto punishment because the State imposed registration punishments on offenders who committed their offenses before the law's enactment but then moved to Indiana after its enactment while under Indiana constitutional law did not punish the same offenders who committed offenses before the law's enactment but never left. The decision is under appeal in the Seventh Circuit Court of appeals.

257. Redington v. State, 121 N.E.3d 1053 (Ind. Ct. App. 2019).

258. Id. at 1054 .

259. Id.

260. Id.

261. Id. at 1064 . 
position. Under this format, "a person could never prove they are not dangerous under section $35-47-14-8$ because once a person has been deemed potentially dangerous in the future, 'the future' becomes essentially endless and nothing that happens - or perhaps more relevantly, does not happen - after the original determination is relevant." 262 The court of appeals found that "the fact that we interpret the language in section 35-47-14-8 to require a new determination when a return of firearms is requested is what keeps the statutory scheme from being unconstitutional as applied, if not unconstitutional on its face."263

In McBride v. State, ${ }^{264}$ the court of appeals declined to address whether defendant's disorderly conduct conviction for recklessly, knowingly, or intentionally making an unreasonable noise by discharging his firearm at the ground next door to a church, after being asked by officers to stop, violated Article 1, Section 32 of the Indiana Constitution "by impermissibly regulating [defendant's] right to bear arms." ${ }^{265}$ The incident stemmed from an escalating dispute between church members and the defendant, who lived next door to the church. After escalating events, defendant continuously discharged his firearm at the ground between his property and the church in an attempt to retaliate against church members for past events. ${ }^{266}$ In addition to his disorderly conduct count, defendant was convicted of intimidation, a Level 5 felony. ${ }^{267}$ The trial court merged all counts into the one judgment for intimidation, finding that all of defendant's convictions stem from a single transaction. ${ }^{268}$

For his constitutional argument, defendant argued that if his intimation conviction is reversed, it would be unconstitutional to convict defendant of disorderly conduct in this situation. ${ }^{269}$ But because defendant's argument was contingent on the outcome of his challenge to his intimidation conviction, which the court of appeals found sufficient evidence in support thereof, the court of appeals declined to address the defendant's constitutional argument. The court did note "that although a person has the right to own guns, he has no right to misuse them or to threaten other people with them."270

\section{DiSTRIBUTION OF POWERS (ARTICLE $3, \S 1$ )}

In Town of Brownsburg v. Fight Against Brownsburg Annexation, ${ }^{271}$ the Indiana Supreme Court affirmed the trial court's judgment for owners of annexed

262. Id. (emphasis in original).

263. Id. at 1065 .

264. McBride v. State, 128 N.E.3d 531, 539 n.4 (Ind. Ct. App. 2019).

265. Id.

266. Id. at 534-36.

267. $I d$. at 533 .

268. Id. at 536 .

269. Id. at 539 n. 4 .

270. Id.

271. Town of Brownsburg v. Fight Against Brownsburg Annexation, 124 N.E.3d 597 (Ind. 2019). 
land who claimed the town failed to meet statutory annexation requirements. In 2013, Brownsburg attempted to annex certain land. A group of landowners remonstrated and sought a declaration that Brownsburg failed to meet the annexation requirements set forth in Ind. Code $\S 36-4-3-13$. The trial court entered judgment for the landowners and against Brownsburg. ${ }^{272}$

In determining whether a municipality followed the statutory requirements for annexation, the court "must afford 'substantial deference' to the municipality's legislative judgment - i.e., to its policy choice to annex the disputed territory[]" but "whether the annexation was lawful is a legal question for the courts." ${ }^{273}$ The Indiana Supreme Court rejected Brownsburg's argument that the substantial deference courts owe municipalities' policy choices also applies to legal questions. ${ }^{274}$ Instead, "[a] trial court assessing the legality of a disputed annexation must weigh and balance the evidence submitted by both sides and not put its thumb on the scale for either." ${ }^{275}$ Separation of powers under Article 3, Section 1 of the Indiana Constitution does not require such deference to the municipality. "This doctrine neither requires judicial review nor forecloses it. Rather, the judicial role in annexation cases is limited to that prescribed by statute." ${ }^{276}$ Because the legislature "subject[s] annexations to judicial review to ensure their legality[,]" the court has a responsibility to determine the statutory criteria are met by considering the evidence and not "by taking a municipality's word for it."277 "Thus, the judicial role is to decide whether the municipality has met the statutory requirements or flouted them. Courts may do no more; but we must do that much."278

In Towne \& Terrace Corp. v. City of Indianapolis, ${ }^{279}$ the court of appeals found that appointment of a receiver over properties owned by the City as a result of the City's failure to pay maintenance fees, assessments, late charges, interest, and attorneys' fees was not a violation of the separation of powers doctrine. Despite finding the issue waived due to the City failing to make the argument at the trial court, the court of appeals rejected the City's argument that the appointment of a receiver over the City's properties violates the separation of powers doctrine. "[O]ur Supreme Court has held that Article 3, Section 1 'relates solely to the state government and officers charged with duties under one of the separate departments of the state, and not to municipal governments and officers. ${ }^{\prime 280}$

272. Id. at 600 .

273. Id. at 603 .

274. Id.

275. Id. (emphasis in original).

276. Id. (internal citations omitted).

277. Town of Brownsburg v. Fight Against Brownsburg Annexation, 124 N.E.3d 597, 604 (Ind. 2019).

278. Id. (internal citations omitted).

279. Towne \& Terrace Corp. v. City of Indianapolis, 122 N.E.3d 846 (Ind. Ct. App. 2019).

280. Id. at 858 (quoting Willsey v. Newlon, 316 N.E.2d 390, 391-92 (Ind. 1974)). 
The Indiana Supreme Court's decision in Horner v. Curry, ${ }^{281}$ while surveying a panoply of cases that had apparently been reconciled over the past twenty-five years, produced among the justices three approaches to standing in constitutional or public rights cases. In Horner, the Indiana Supreme Court held that a group of taxpayers had standing to litigate their claim that the Indiana civil forfeiture statute unconstitutionally distributes forfeiture revenue from the Common School Fund. ${ }^{282}$ While the Indiana Constitution "imposes no 'case or controversy' restriction on the "judicial power of the State[]" as Article III of the U.S. Constitution imposes, "the express distribution-of-powers clause in our fundamental law performs a similar function, serving as a principal justification for judicial restraint." 283

In determining that the taxpayers had a private right to enforce the Common School Fund provision of the Indiana Constitution, Justice Massa, writing for the plurality, found "our courts have been sympathetic toward standing, permitting private plaintiffs to vindicate a variety of claims, whether to enforce a public duty or to challenge the expenditure of public funds[]" while also recognizing a shift toward judicial restraint. ${ }^{284}$ To clarify the limits of standing, Justice Massa distinguished between taxpayer standing and public standing:

While both doctrines overlap to some extent, unique rationales distinguish them. Taxpayer standing generally implicates a challenge to some government action that involves the expenditure or appropriation of public funds ... Public standing, on the other hand, involves a challenge to "virtually any government action," so long as there's a "substantial public interest, as determined by the court overseeing the lawsuit." Whereas the former doctrine has at least some "connection to an injury-in-fact, however tenuous it may be," the latter doctrine typically "has no basis in, and cannot be traced to, a particularized injuryin-fact." $" 285$

Justice Massa's opinion seemed to question the validity of the public standing doctrine in light of the separation-of-powers principles that animate standing rules in the first place and asked, "[i]f all government action is subject to judicial review, what purpose does the political process serve?"286 But he declined to explicitly call for abandoning the doctrine, because the case before the court clearly implicated that the concept of taxpayer standing. "[T]o establish taxpayer standing, a plaintiff must (1) raise a challenge seeking to vindicate an express constitutional limitation on the expenditure of public funds, (2) demonstrate some personal stake in the outcome of the controversy, and (3) show 'extreme

281. Horner v. Curry, 125 N.E.3d 584 (Ind. 2019).

282. Id. at 587. This case has two constitutional issues. The other is discussed in $\S \mathrm{XV}$, infra.

283. Id. at 589 .

284. Id. at 591-92.

285. Id. at 594 (internal citations omitted).

286. Id. at 595 . 
circumstances' warranting judicial intervention."287 In applying this standard, Justice Massa found the taxpayers to have standing to litigate their claim because (i) "their claim clearly indicates an express constitutional limitation on the expenditure or appropriation of public funds[,]" (ii) the taxpayers have an interest in protecting the Common School Fund from waste, and (iii) extreme circumstances exist due to the alleged legislative abuse and constitutional question. ${ }^{288}$

Chief Justice Rush, in concurring, found that precedent establishes the taxpayers' standing in this case, as a category of public standing ${ }^{289}$ but that Justice Massa incorrectly criticized precedent relating to the public-standing doctrine. ${ }^{290}$ In his criticism, the Chief Justice argued, Justice Massa "imprudently drives a knife into not only the heart of the judiciary's duty to ensure that each branch of government stays within its assigned lane, but also this court's precedent and integrity as a decision-making institution."291

Justice Slaughter, in concurring in judgment, would have found the taxpayers to lack standing because "Article 3, Section 1 requires, among other things, that a plaintiff suffer individualized injury in fact and not a generalized harm indistinct from the public at large. Our prevailing judicial doctrines that permit taxpayer and citizen (also known as public-interest) standing are incompatible with this constitutional command." ${ }^{292}$ Thus, in light of the three differing opinions, it is an open question whether a plaintiff who does not have an interest undifferentiated from the public at large has standing to bring a constitutional challenge not involving an expenditure or appropriation.

\section{ARTICLE 4, $\S \S 22 / 23$ - No SPECIAL OR LOCAL LAWS}

In City of Gary v. Smith \& Wesson Corp., the court of appeals rejected the City's argument that a 2015 amendment providing retroactive immunity to firearms manufacturers was an unconstitutional special law. ${ }^{293}$ The legislature enacted the immunity amendment to be effective four days before the City had filed its suit against a firearms manufacturer. The City argued that this amendment is a special law because it specifically targeted the City's case by setting the effective date one day before the date of the City's complaint. ${ }^{294}$

Article 4, Section 22 "prohibits 'special' legislation on certain subjects, and Section 23 provides that in those cases and 'in all other cases where a general law can be made applicable, all laws should be general, and of uniform operation

287. Id. at 596 .

288. Id.

289. Chief Justice Rush emphasized the important role the public-standing doctrine serves "in maintaining the separation of powers, with checks and balances, in state government." Id. at 608 .

290. Id. at 609.

291. Id. at 610 .

292. Id. at 612 .

293. City of Gary v. Smith \& Wesson Corp., 126 N.E.3d 813 (Ind. Ct. App. 2019).

294. Id. at 826 . 
throughout the state." ${ }^{295}$ First, courts must "determine whether the law is general or special. If the law is general, we then determine whether it is applied generally throughout the State; if it is special, we must determine whether it is constitutionally permissible." ${ }^{296}$ However, the court did not need to make a determination here because it found the State's argument persuasive that

even if the Amendment is a special law, it is constitutionally permissible because it "ensured that [Section 34-12-3-3] would apply uniformly across the State by specifically applying the statutory immunity to the one case remaining outside its reach - a case to which the law undoubtedly could have applied in the first place."297

In City of Hammond v. Herman \& Kittle Properties, Inc., the Indiana Supreme Court found unconstitutional an exemption to the fee restriction statute that permitted the cities of Bloomington and West Lafayette to charge landlords higher fees for rental properties while all other cities' fees are capped at $\$ 5 .^{298}$ The State and landlord argued that the special treatment for cities of Bloomington and West Lafayette is warranted because of the unique characteristics of these cities: "the cities' high percentage of renter-occupied properties, their large universities that draw young and unsophisticated renters, and their long-running rental-fee programs." 299

Under Article 4, Section 23, "[s]pecial legislation is constitutional only if an affected class's unique characteristics justify the differential legislative treatment." "300 "Our analysis of special legislation begins with the oft-stated presumption in favor of a statute's constitutionality. With that presumption in mind, we then determine whether the statute's proponent has met its burden to show that a general law cannot be made applicable." ${ }^{301}$ Here, the Indiana Supreme Court found that the exemption statute's proponents failed to carry this burden.

The court found that while Bloomington and West Lafayette have a high percentage of renter-occupied properties, other Indiana cities have similarly high percentages of such properties so that the "moderately higher percentages" in Bloomington and West Lafayette are not sufficiently defining characteristics. ${ }^{302}$ The statute's proponents also failed to articulate why allegedly unsophisticated renters is reason to charge fees over $\$ 5$. Finally, the court rejected the proponents' argument that Bloomington and West Lafayette's long-running rental-fee programs justify special treatment. "The Fee Exemption is precisely the type of law our framers sought to eliminate during the 1850-1851 Constitutional Convention. While the bar to establish the constitutionality of special legislation

\author{
295. Id. at 825 . \\ 296. Id. at 826 . \\ 297. Id. (internal citations omitted). \\ 298. City of Hammond v. Herman \& Kittle Props., Inc., 119 N.E.3d 70 (Ind. 2019). \\ 299. Id. at 74 . \\ 300. Id at 78 . \\ 301. Id. at 73 . \\ 302. Id. at 85 .
}


is by no means a high one, the proponent still must justify the special treatment afforded to the specified class." ${ }^{\text {0 } 03}$

\section{ARTICLE 7, § 7 - JUdiCIAL CIRCUITS}

In In re Robison, the Indiana Supreme Court clarified "municipal courts' power to administer infraction cases and infraction deferral agreements and [] caution[ed] judicial officers on the impropriety of assuming the prosecutor's duties." ${ }^{304}$ This case involved a former city court judge's disciplinary proceedings relating to alleged violations of the Code of Judicial Conduct by the judge's improper use of the Allen County prosecutor's signature stamp to execute infraction agreements. Although the respondent settled with the Indiana Commission on Judicial Qualifications, the Indiana Supreme Court issued this opinion to clarify that

trial courts may neither dismiss these deferral cases sua sponte nor use the prosecutor's signature stamp to administer or execute infraction deferral agreements. Either action is an improper assumption of the prosecutor's distinct role and flouts the Code of Judicial Conduct's overarching goal of an independent, fair, and impartial judiciary. ${ }^{305}$

The supreme court stressed that the status of municipal courts "as 'special courts' does not absolve them of the duties of a separate but co-equal branch of government. Municipal court judges, like all judges, must endeavor to maintain, preserve, and protect the independence of Indiana's judiciary, even when administering the lowest-level civil and criminal offenses." ${ }^{306}$

\section{ARTICLE $8, \S \S 1 / 2 / 3$ - PROVISION FOR PUBLIC SCHOOLS VIA THE COMMON FUND}

In Horner v. Curry, ${ }^{307}$ the Indiana Supreme Court rejected taxpayers' claim that the Indiana civil forfeiture statute violates Article 8, Section 2 by diverting funds from the Common School Fund..$^{308}$ "The Indiana Constitution imposes on the General Assembly a duty 'to provide, by law, for a general and uniform system of Common Schools, wherein tuition shall be without charge, and equally open to all." ${ }^{309}$ To fund this goal, the Indiana Constitution creates a Common School Fund, which includes revenue from "all forfeitures which may accrue." 310 The civil forfeiture statute "directs the transfer of proceeds from seized property

303. Id. at 86-87.

304. In re Robison, 116 N.E.3d 452, 454 (Ind. 2019).

305. Id.

306. Id. at 454-55.

307. Horner v. Curry, 125 N.E.3d 584 (Ind. 2019).

308. This case has two constitutional issues. The other is discussed in $\S$ XII, supra.

309. Id. at 587.

310. Id. 
'to the treasurer of state for deposit in the common school fund." ${ }^{\prime 311}$ But before funds are deposited in the Common Fund, law enforcement is permitted to reimburse costs related to the forfeiture and legislature is permitted to allocate other portions. The taxpayers argued this reimbursement of law enforcement costs and to unrelated allocations violates Article 8, Section 2 by diverting funds from the Common Fund.

As a threshold matter, Justice Massa, writing for the plurality, found that Article 8, Section 2 applies to civil forfeitures by reviewing case and legislative history. ${ }^{312}$ Then, looking to the text, structure, and history of Article 8, Section 2, Justice Massa held that the legislature may determine when and how funds are deposited into the Common School Fund and that the civil forfeiture statute is constitutional. While Justice Massa acknowledged the "critical role" public schools have in the lives of children, he deferred to the legislature to determine if and how to direct funds to the Common School Fund by way of the civil forfeiture statute. ${ }^{313}$ "Because our constitution's text, structure, and history clearly show that article 8, section 2 was 'not self-acting in [its] operation,' we hold that the General Assembly may decide how and when forfeiture proceeds accrue to the Common School Fund."

In her dissent, Chief Justice Rush said she would have found the civil forfeiture statute unconstitutional because "Article 8, Section 2 imposes a condition on civil-forfeiture legislation: all forfeitures, save offset costs, must go to the Common School Fund." ${ }^{315}$ While Chief Justice Rush would continue to permit the costs of forfeiture to be expensed prior to the deposit of funds in the Common School Fund, she disagrees with allocations that "bear no correlation to expenses incurred in obtaining the forfeiture." ${ }^{316}$

311. Id. (quoting IND. CODE $\S 34-24-1-4(\mathrm{~d})$ ).

312. Id. at 597-98.

313. Id.

314. Horner, 125 N.E.3d. at 607 (internal citations omitted).

315. Id. at 610 .

316. Id. at $611 ;$ id. at 602 n. 22. 